\title{
Molecular Dynamics Study of the Structural Properties of Calcium Aluminosilicate Slags with Varying $\mathrm{Al}_{2} \mathrm{O}_{3} / \mathrm{SiO}_{2}$ Ratios
}

\author{
Kai ZHENG, ${ }^{1)}$ Zuotai ZHANG, ${ }^{1 / *}$ Feihua YANG $^{2)}$ and Seetharaman SRIDHAR ${ }^{3)}$
}

1) Department of Energy and Resources Engineering, College of Engineering, Peking University, Beijng, 100871 P.R.China. Email: zhengkai890406@163.com, zuotaizhang@coe.pku.edu.cn 2) Beijing Building Materials Academy of Sciences Research, Beijing, 100041 P.R.China. E-mail: chyangfeihua@126.com 3) Department of Materials Science and Engineering, Carnegie Mellon University, Pittsburgh, PA, USA. E-mail: sridhars@andrew.cmu.edu

(Received on July 15, 2011; accepted on October 24, 2011)

\begin{abstract}
Molecular dynamics simulation was explored to investigate the change of structure of calcium aluminosilicate slags with varying $\mathrm{Al}_{2} \mathrm{O}_{3} / \mathrm{SiO}_{2}$ ratios at a fixed $\mathrm{CaO}$ content. In practice the results of the study are relevant to the significant changes in slag structure caused by the changes in chemical composition during continuous casting of steels containing high amounts of dissolved aluminum. It was found that $\mathrm{Q}^{4}$ tetrahedral species (tetrahedron with four bridging oxygens) increase while NBOs (non-bridging oxygen) decreases with increasing $\mathrm{Al}_{2} \mathrm{O}_{3} / \mathrm{SiO}_{2}$ mole ratio, suggesting that a more polymerized network was formed. The concentration of oxygen tricluster increased dramatically up to $24 \%$ with increasing $\mathrm{Al}_{2} \mathrm{O}_{3} / \mathrm{SiO}_{2} \mathrm{~mole}$ ratio, and the coordination number for $\mathrm{Al}\left(\mathrm{CN}_{\mathrm{Al}-\mathrm{O}}\right)$ was also observed to increase from 4.02 for sample CAS1 to 4.11 for sample CAS11, suggesting that high coordination number of Al presents in the slag melt with the substitution of $\left[\mathrm{AlO}_{4}\right]$ for $\left[\mathrm{SiO}_{4}\right]$. NBOs prefer to be coordinated with $\mathrm{Si}$ and $\mathrm{Al}$ tends to be localized in more polymerized environment as network intermediate phases. The degree of Al avoidance was calculated and the $\mathrm{Al}$ avoidance principle is applicable in the $\mathrm{SiO}_{2}$ rich regions.
\end{abstract}

KEY WORDS: molecular dynamics; calcium aluminosilicate slag; slag structure; $\mathrm{Al}_{2} \mathrm{O}_{3} / \mathrm{SiO}_{2}$ ratio.

\section{Introduction}

Aluminosilicate glasses and melts are not only among the major constituents of Earth's mantle and crust but also play a significant role in industrial process such as glass and ceramic manufacture, ironmaking and steelmaking. Among them the calcium aluminosilicate (CAS) ternary system is particularly attractive. For instance, CAS glasses have been applied extensively by virtue of their excellent optical, mechanical properties and their refractory features, and the ternary melts is also the main compositions of slag used in ironmaking and steelmaking processes. It is well known that the macroscopic physical and chemical properties of CAS system is determined by the structure, i.e. the size of the charged polymeric units that comprise the melt and it is therefore important to acquire the structure's atomic-scale information. This has been studied through various sorts of techniques e.g. Nuclear Magnetic Resonance (NMR), ${ }^{1-4)} \mathrm{X}-$ Ray absorption spectroscopy (XAS), ${ }^{5,6}$ neutron diffraction, ${ }^{7,8)}$ Raman scattering ${ }^{9,10)}$ and molecular dynamics (MD) simulation. ${ }^{11-14)}$ However, previous studies mainly paid their attention to CAS glasses or slags with a low silica mole fraction or a varying $\mathrm{CaO}$ proportion. How the structure changes with varying $\mathrm{Al}_{2} \mathrm{O}_{3} / \mathrm{SiO}_{2}$ ratio has not been investigated so far.

In recent years, high strength steels such as Transformation Induced Plasticity (TRIP) steel or Twining Induced Plasticity (TWIP) steels et al. have drawn wide attentions because of its lightweight automotive applications. The additional $\mathrm{Al}$ in the steel is expected to react with the slags containing $\mathrm{SiO}_{2}$ and the reaction increases the $\mathrm{Al}_{2} \mathrm{O}_{3} / \mathrm{SiO}_{2}$ ratio during the casting process, causing great process control problems and significant changes in structural and thermophysical properties. It is well known that the $\left[\mathrm{SiO}_{4}\right]$ and $\left[\mathrm{AlO}_{4}\right]$ tetrahedra in CAS system are the fundamental structural units, which are connected by sharing oxygen atoms to form a three-dimensional network and $\mathrm{Ca}$ atoms are dispersed in those networks. The charge deficiency of $\left[\mathrm{AlO}_{4}\right]$ tetrahedron must be compensated by $\mathrm{Ca}$ cations, i.e., $\mathrm{Ca}$ atoms may play the role of network modifier or charge balancing, depending on the $\mathrm{CaO} / \mathrm{Al}_{2} \mathrm{O}_{3}$ ratio. Furthermore, the 'Al avoidance' principle has been debated in literature regarding its accuracy and the range of application. Structural defects such as non-bridging oxygen, ${ }^{12,15)}$ tricluster ${ }^{11,16-18)}$ and $\mathrm{Al}^{\mathrm{V}}{ }^{19-21)}$ also occupy considerable quantities and have deep influences on the system's structure and properties. In this paper, MD (Molecular Dynamic) simulation is applied to the CAS slags at a fixed $\mathrm{CaO}$ content and various molar ratios between $\mathrm{SiO}_{2}(64 \%$ to $24 \%)$ and $\mathrm{Al}_{2} \mathrm{O}_{3}$ (6\% to $\left.46 \%\right)$ to promote understanding the change of the primary structural properties with varying $\mathrm{Al}_{2} \mathrm{O}_{3} / \mathrm{SiO}_{2}$ ratios, including partial radial distribution function (RDF), coordination number $(\mathrm{CN})$, distributions of different types of oxygen, bond lengths and bond angles. These studies may provide clues to how to control or engineer slags used in casting high strength steels. 


\section{Simulation Method}

In the molecular dynamic simulations of aluminosilicate slags, the choice of a suitable potential function and its corresponding parameters is critical for the success of a simulation. There are several potential functions such as Born-Mayer-Higgins (BMH) and Stillinger-Weber (SW) potentials which were generally used during past years, and a pair atom potential function of BMH form which has been successfully used for CAS glasses or melts ${ }^{11-13)}$ was applied here:

$$
U\left(r_{i j}\right)=\frac{q_{i} q_{j}}{r_{i j}}+A_{i j} \exp \left(-B_{i j} \cdot r_{i j}\right)
$$

where $U\left(r_{i j}\right)$ is the interatomic pair potential, $q_{i}, q_{j}$ are the selected charges and $r_{i j}$ denotes the distance between atoms $i$ and $j$. The first term of right hand side corresponds to the Coulombic interaction, which can be calculated using the standard charge of each element. The second term represents inter-core short range repulsion interaction. $A_{i j}$ and $B_{i j}$ are adjustable parameters and the determined values are listed in Table 1. Those values have been proven successful in the simulation of aluminosilicate slags. ${ }^{13,19)}$ The Ewald method was used to calculate the Coulomb interaction for each atom and the cutoff of potential was $10 \AA$ when eval-

Table 1. Parameters for the BMH potentials.

\begin{tabular}{ccrc}
\hline Atom 1 & Atom 2 & \multicolumn{1}{c}{$\mathrm{A}_{\mathrm{ij}}(\mathrm{eV})$} & $\mathrm{B}_{\mathrm{ij}}(1 / \AA)$ \\
\hline $\mathrm{Ca}$ & $\mathrm{Ca}$ & 9684.976 & 3.448 \\
$\mathrm{Ca}$ & $\mathrm{Si}$ & 1362.401 & 4.492 \\
$\mathrm{Ca}$ & $\mathrm{Al}$ & 4879.785 & 3.448 \\
$\mathrm{Ca}$ & $\mathrm{O}$ & 3718.745 & 3.448 \\
$\mathrm{Si}$ & $\mathrm{Si}$ & $1.866 \times 10^{19}$ & 40.00 \\
$\mathrm{Si}$ & $\mathrm{Al}$ & 2219.246 & 3.448 \\
$\mathrm{Si}$ & $\mathrm{O}$ & 223440.540 & 7.018 \\
$\mathrm{Al}$ & $\mathrm{Al}$ & 2444.136 & 3.650 \\
$\mathrm{Al}$ & $\mathrm{O}$ & 1945.759 & 3.546 \\
$\mathrm{O}$ & $\mathrm{O}$ & 15812.842 & 3.846 \\
\hline
\end{tabular}

uating the repulsive forces.

As mentioned, the present simulation chooses the samples of the ternary system $\mathrm{CaO}-\mathrm{SiO}_{2}-\mathrm{Al}_{2} \mathrm{O}_{3}$ with varying $\mathrm{Al}_{2} \mathrm{O}_{3} / \mathrm{SiO}_{2}$ mole ratio at a fixed mole ratio of $\mathrm{CaO}$ which is a simplification of a mold slag that is currently under trial in the steel industry for casting of TRIP steels. ${ }^{22}$ The samples were divided into 11 groups with varying $\mathrm{Al}_{2} \mathrm{O}_{3} / \mathrm{SiO}_{2}$ mole ratio as shown in Table 2. The numbers of different atoms are then decided according to the mole fractions, given that the total number is about 4000 . The density of every sample was calculated with a model proposed by Courtial and Dingwell. ${ }^{23)}$ Assuming that all 4000 atoms are put in a cubic model box, the molar mass and density together decide the length of box, which is also listed in Table 2 .

Since the number of atoms is always smaller than wanted due to the calculation resources, periodic boundary conditions are applied on all faces of the model box to create an infinite system with no boundaries. During the simulation the leap frog integration method was used and the initial velocities were drawn randomly from a Maxwell-Boltzmann distribution. Before the simulation process starts, four types of atoms with appropriate composition were placed randomly into the model box and equilibrated at $5000 \mathrm{~K}$ for 30000 time steps (the time for each step is $1 \mathrm{fs}$ ) to compose the initial configuration. Another type of initial configuration was composed by Metropolis Monte Carlo method. Subsequently, the sample was cooled down from $5000 \mathrm{~K}$ to $2000 \mathrm{~K}$ in steps of $500 \mathrm{~K}$. During every step the relaxation of total potential energy was carried out for 20 ps. Then the temperature was fixed at $2000 \mathrm{~K}$ for another 30000 time steps, and the partial radial distribution functions (RDF) were therefore achieved and the balance conformations were collected to do the microscopic structure analysis during this period. We also performed another group of simulations whose simulated time in every step was only half of the previous one, and no significant difference was observed in the results of these two groups. So, the selected simulation method is feasible and the results are convincible. All simulations are performed in NVT ensemble (i.e. the volume and temperature of the samples are controlled) and carried out using Materials Explorer program (FUJITSU LIMITED).

Table 2. The composition of slag melts, atomic numbers, density and the length of model cubic box.

\begin{tabular}{|c|c|c|c|c|c|c|c|c|c|c|}
\hline \multirow{2}{*}{ Groups } & \multicolumn{3}{|c|}{ Mole fraction } & \multicolumn{5}{|c|}{ Atomic number } & \multirow{2}{*}{$\begin{array}{l}\text { Density } \\
\mathrm{g} / \mathrm{cm}^{3}\end{array}$} & \multirow{2}{*}{ Length $/ \AA ̊$} \\
\hline & $\mathrm{CaO}$ & $\mathrm{SiO}_{2}$ & $\mathrm{Al}_{2} \mathrm{O}_{3}$ & $\mathrm{Ca}$ & $\mathrm{Si}$ & $\mathrm{Al}$ & $\mathrm{O}$ & total & & \\
\hline CAS1 & 0.3 & 0.64 & 0.06 & 425 & 908 & 170 & 2496 & 3999 & 2.488 & 38.7320 \\
\hline CAS2 & 0.3 & 0.6 & 0.1 & 414 & 827 & 276 & 2482 & 3999 & 2.510 & 38.6067 \\
\hline CAS3 & 0.3 & 0.56 & 0.14 & 402 & 752 & 376 & 2470 & 4000 & 2.531 & 38.4876 \\
\hline CAS4 & 0.3 & 0.52 & 0.18 & 392 & 680 & 470 & 2457 & 3999 & 2.551 & 38.3728 \\
\hline CAS5 & 0.3 & 0.48 & 0.22 & 382 & 612 & 560 & 2446 & 4000 & 2.571 & 38.2645 \\
\hline CAS6 & 0.3 & 0.44 & 0.26 & 372 & 547 & 646 & 2435 & 4000 & 2.590 & 38.1587 \\
\hline CAS7 & 0.3 & 0.4 & 0.3 & 363 & 485 & 728 & 2425 & 4001 & 2.608 & 38.0635 \\
\hline CAS8 & 0.3 & 0.36 & 0.34 & 355 & 427 & 804 & 2415 & 4001 & 2.626 & 37.9677 \\
\hline CAS9 & 0.3 & 0.32 & 0.38 & 347 & 370 & 878 & 2404 & 3999 & 2.644 & 37.8666 \\
\hline CAS10 & 0.3 & 0.28 & 0.42 & 339 & 316 & 950 & 2396 & 4001 & 2.660 & 37.7872 \\
\hline CAS11 & 0.3 & 0.24 & 0.46 & 332 & 265 & 1016 & 2386 & 3999 & 2.677 & 37.6937 \\
\hline
\end{tabular}



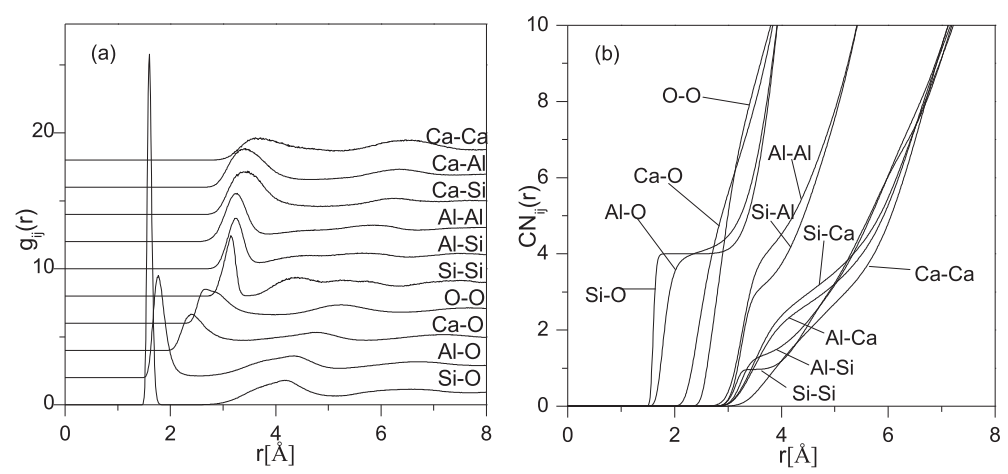

Fig. 1. (a) The RDFs of simulation and (b) the running CNs of sample CAS9.

\section{Results and Discussion}

\subsection{Radial Distribution Functions (RDF) and Coordi- nation Numbers $(\mathrm{CN})$}

The RDFs indicate the average number of atoms of atomic species $j$ that are located at a distance $\mathrm{r}$ from a target atomic species $i$ atoms and it is defined as follows,

$$
g_{i j}(r)=\frac{V}{N_{i} N_{j}} \sum_{k}^{N_{i}} \frac{n_{k j}(r-\Delta r / 2, r+\Delta r / 2)}{4 \pi r^{2} \Delta r}
$$

where $N_{i}\left(N_{j}\right)$ is the total number of atomic species $i(j)$ atoms included in the system, $n_{k j}$ is the number of atomic species $k$ atoms included in a spherical shell of thickness $\Delta r$ located at a distance $r$, and $V$ is the volume of the system. The RDFs not only describe the character of short-range order and long-range disorder of the slag melt, but also provide the basic structural information including the average bond lengths and average coordination numbers. The running $\mathrm{CN}$ is calculated through integration of the corresponding RDF and the chosen cutoff is the position of the first valley of RDF.

$$
N_{i j}(r)=\frac{4 \pi N_{j}}{V} \int_{0}^{r} r^{2} g_{i j}(r) \mathrm{d} r
$$

Figure 1 shows the curves of RDFs and running CNs for all atomic pairs of the sample CAS9 as an example. The first peaks of $\mathrm{Si}-\mathrm{O}, \mathrm{Al}-\mathrm{O}$ and $\mathrm{Ca}-\mathrm{O}$ RDFs, which correspond to the most probable bond distances, are equal to $1.60,1.77$ and $2.40 \AA$, respectively. These are in agreement with the previous reports ${ }^{7,13,24)}$ that measured by an X-ray and neutron diffraction techniques or obtained through MD simulations using the SW potential function. It is also noted that the first peak of $\mathrm{Si}-\mathrm{O}$ shows a narrow and sharp shape, suggesting that the $\left[\mathrm{SiO}_{4}\right]$ tetrahedron is very stable and the stable feature of $\left[\mathrm{SiO}_{4}\right]$ tetrahedron is partially inherited by $\left[\mathrm{AlO}_{4}\right]$ tetrahedral unit. The running $\mathrm{CN}$ also helps to promote an understanding the structural properties of the melts. For instance, the running $\mathrm{CN}_{\mathrm{Si}-\mathrm{O}}$ occupies a smooth platform equal to 4 at the vertical axis, indicating that the overwhelming majority of $\mathrm{Si}$ atoms are 4-coodinated with oxygen. The curve of running $\mathrm{CN}_{\mathrm{Al}-\mathrm{O}}$ also possesses a slanting platform, which indicates that the average $\mathrm{CN}_{\mathrm{Al}-\mathrm{O}}$ is 4.10 for sample CAS9. This on one hand demonstrates that the Al tetrahedral unit is not as stable as the $\left[\mathrm{SiO}_{4}\right]$ tetrahedron, and on the other hand suggests that some high-coordinated Al units do exist in the CAS slags. ${ }^{11,15,16)} \mathrm{Ca}$ in the system has no significant structure that is stable and the simulated results

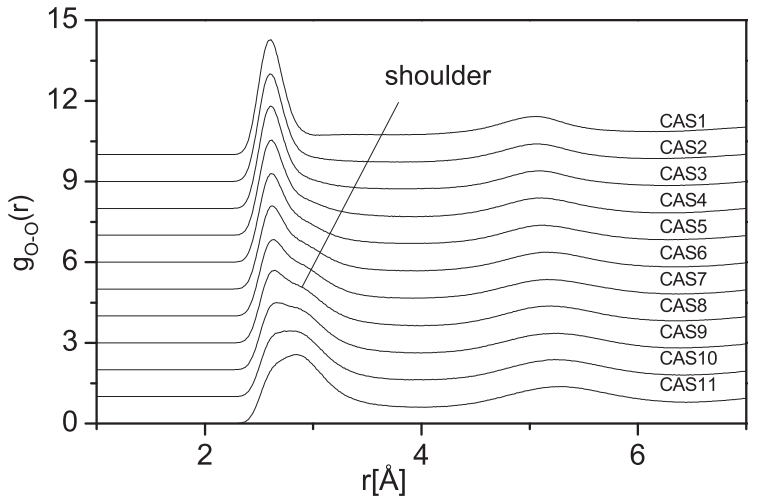

Fig. 2. RDFs for $\mathrm{O}-\mathrm{O}$ pairs of all CAS slags.

indicate that the running $\mathrm{CN}_{\mathrm{Ca}-\mathrm{O}}$ is 7.02 , which is a litter larger than the experimental results by XAS. ${ }^{25}$ )

There is an interesting transformation of the first peak of $\mathrm{O}-\mathrm{O}$ atomic pair, as shown in Fig. 2, and the $\mathrm{O}-\mathrm{O}$ peaks provide the detailed information about what is the major structural unit in the slags. In the $\mathrm{SiO}_{2}$ rich region (CAS1 to CAS6), the first peak value equals to $2.61 \pm 0.01 \AA$, corresponding to the typical distance between oxygen atoms in a $\left[\mathrm{SiO}_{4}\right]$ tetrahedron. While the value converts to $2.85 \AA$ in an $\mathrm{Al}_{2} \mathrm{O}_{3}$ rich region (CAS11), corresponding to the $\mathrm{O}-\mathrm{O}$ distance in an $\left[\mathrm{AlO}_{4}\right]$ tetrahedron. The peculiar peak with an accompanying shoulder appears in the curve for sample CAS8 as the content of $\mathrm{SiO}_{2}$ and $\mathrm{Al}_{2} \mathrm{O}_{3}$ is approximately equivalent, demonstrating that $\left[\mathrm{AlO}_{4}\right]$ units have already occupied a considerable part of the networks. Similar results were also reported by $\mathrm{XAS}^{7}$ ) and the MD simulations for other slag systems. ${ }^{19)}$

The variation of structural properties of CAS slags with composition was studied and the results were shown in Fig. 3. It can be seen that the $\left[\mathrm{SiO}_{4}\right]$ tetrahedral unit has proven its high stability by the first peak's position $(1.60 \AA)$ and coordination number (4.00) which keep constant with varying $\mathrm{Al}_{2} \mathrm{O}_{3} / \mathrm{SiO}_{2}$ ratio. A small alteration is detected in $\mathrm{CN}_{\mathrm{Al}-\mathrm{O}}$ from 4.02 to 4.11 , indicating that the $\mathrm{Al}^{\mathrm{V}}$ or $\mathrm{Al}^{\mathrm{VI}}$ units may appear and increases with an increasing $\mathrm{Al}_{2} \mathrm{O}_{3} / \mathrm{SiO}_{2}$ ratio. It is interesting to note that the role of $\mathrm{Ca}$ changed from network modifiers to charge balancing, followed by a noticeable increase in both peak's position and coordination numbers. This may suggest that the average distance between $\mathrm{Ca}$ and tetrahedral units becomes bigger and $\mathrm{Ca}$ must provide charge compensating for more $\left[\mathrm{AlO}_{4}\right]$ units. Furthermore, the coordination numbers of next-nearest neighbors around 


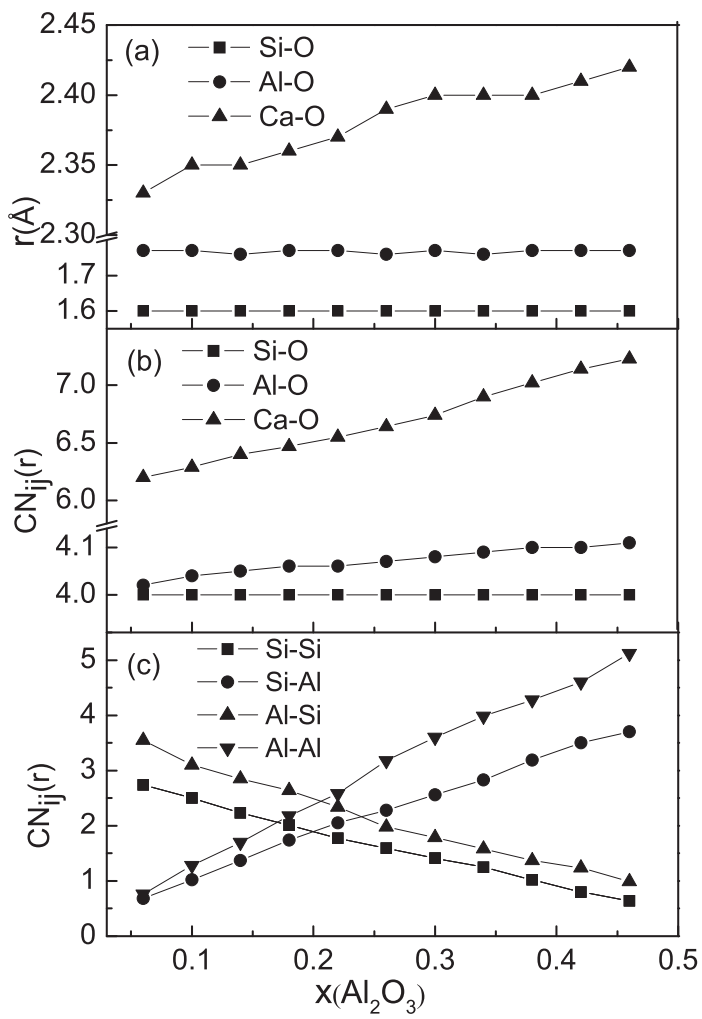

Fig. 3. (a) The position of the first peak of RDFs, (b) coordination numbers of $\mathrm{Si}-\mathrm{O}, \mathrm{Al}-\mathrm{O}$ and $\mathrm{Ca}-\mathrm{O}$, (c) coordination numbers of $\mathrm{Si}-\mathrm{Si}, \mathrm{Si}-\mathrm{Al}, \mathrm{Al}-\mathrm{Si}$ and $\mathrm{Al}-\mathrm{Al}$ as a function of mole fraction of $\mathrm{Al}_{2} \mathrm{O}_{3}$.

the network-former cations are recorded in Fig. 3(c). Special attention should be paid that $\mathrm{CN}_{\mathrm{Si}-\mathrm{Si}}$ and $\mathrm{CN}_{\mathrm{Al}-\mathrm{Al}}$ reach the maximum for samples CAS1 (2.74) and CAS11 (5.12), respectively, and the latter is almost twice as much as the former even when the content of $\mathrm{Al}_{2} \mathrm{O}_{3}$ in sample CAS11 is smaller than that of $\mathrm{SiO}_{2}$ in sample CAS1. This implies that $\mathrm{Al}$ is more likely to aggregate to form some more complicated structural units.

Therefore, it can be seen from above results that the $\left[\mathrm{SiO}_{4}\right]$ tetrahedral unit is very stable, and the microstructure change in CAS slag melt is mainly due to the amphoteric behavior of alumina. The simulation indicates that the running $\mathrm{CN}_{\mathrm{Al}-\mathrm{O}}$ increases from 4.02 to 4.11 , suggesting that high coordination number of $\mathrm{Al}$ presents in the slag melt with the substitution of $\left[\mathrm{AlO}_{4}\right]$ for $\left[\mathrm{SiO}_{4}\right]$ and the role of $\mathrm{Ca}$ changes from network modifiers to charge balancing.

\subsection{BOs, NBOs and Oxygen Triclusters}

Before studying balance configurations out of final 30000 time steps, accurate coordinates of every atom in the cubic model box, as the fundamental factor of microstructural analysis, were saved to calculate the distances between two atoms and angles shaped by three atoms and thereby to get the distribution of them. As shown in Fig. 1(a), the RDFs of $\mathrm{Si}-\mathrm{O}$ and $\mathrm{Al}-\mathrm{O}$ have their first valleys whose corresponding $\mathrm{x}$-axis values are around 2.0 and $2.5 \AA$ respectively, meaning that in those radial ranges from $\mathrm{Si}$ or $\mathrm{Al}$ the probability of finding $\mathrm{O}$ atoms is very close to zero. The cutoff radius $(2.0 \AA$ for $\mathrm{Si}$ and $2.5 \AA$ for $\mathrm{Al}$ ) was therefore decided, where $\mathrm{O}$ atom was considered to be coordinated with $\mathrm{Si}$ or $\mathrm{Al}$ atom. According to this criterion, each $\mathrm{O}$

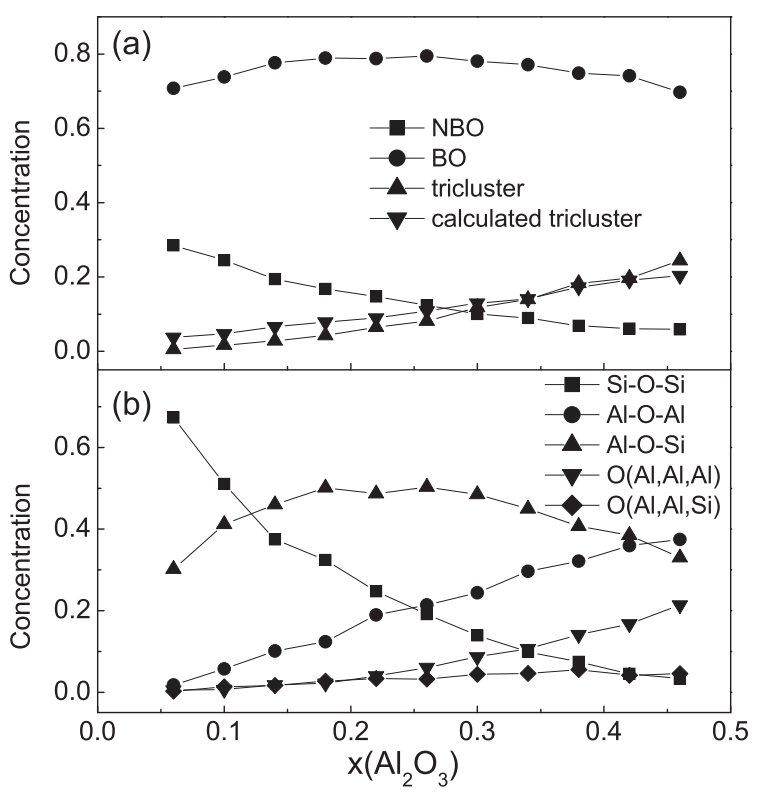

Fig. 4. Concentration of different types of $\mathrm{O}$ as a function of mole fraction of $\mathrm{Al}_{2} \mathrm{O}_{3}$.

Table 3. Relative contents of $\mathrm{Ca}-\mathrm{O}_{\mathrm{nb}}-\mathrm{Si}$ and $\mathrm{Ca}-\mathrm{O}_{\mathrm{nb}}-\mathrm{Al}$. The values are calculated by $\left[\mathrm{Ca}-\mathrm{O}_{\mathrm{nb}}-\mathrm{Si}\right] /\left[\mathrm{SiO}_{2}\right]$ and $\left[\mathrm{Ca}-\mathrm{O}_{\mathrm{nb}}-\right.$ $\mathrm{Al}] /\left(2\left[\mathrm{Al}_{2} \mathrm{O}_{3}\right]\right)$.

\begin{tabular}{lllllll}
\hline & CAS1 & CAS3 & CAS5 & CAS7 & CAS9 & CAS11 \\
\hline NBO (Si) & 0.422 & 0.313 & 0.243 & 0.186 & 0.146 & 0.142 \\
NBO (Al) & 0.124 & 0.068 & 0.070 & 0.043 & 0.029 & 0.028 \\
\hline
\end{tabular}

atom was marked as a specific type by the number of networkformer atoms that it was coordinated with.

The numbers of BO, NBO and triclusters were counted using the aforementioned method and the results are presented in Fig. 4(a), where tricluster indicates that the oxygen atom is coordinated with three network formers. Free oxygens which link two network-modifiers $(\mathrm{Ca}-\mathrm{O}-\mathrm{Ca})$ also appear in the system with a very small fraction (less than $0.2 \%$ ), and this may be due to the fact that the $\mathrm{Ca}-\mathrm{O}-\mathrm{Ca}$ sites are energetically unstable and not able to exist for long. The proportion of NBOs falls remarkably from $28.5 \%$ to $5.9 \%$ with an increasing $\mathrm{Al}_{2} \mathrm{O}_{3} / \mathrm{SiO}_{2}$ ratio, which is in conformity with the conventional concept that when the content of $\mathrm{Ca}$ exceeds that needed for charge compensating, $\mathrm{T}-\mathrm{O}-$ $\mathrm{T}$ ( $\mathrm{T}$ is $\mathrm{Si}$ or $\mathrm{Al}$ ) linkages will be broken to form NBOs. Nevertheless, NBOs still hold a considerable percentage even when $\mathrm{CaO} / \mathrm{Al}_{2} \mathrm{O}_{3}$ ratio is equal or less than 1, as many previous works have demonstrated. ${ }^{11,26)}$ Despite the small fraction, NBOs are divided into two groups, namely $\mathrm{Ca}-$ $\mathrm{O}_{\mathrm{nb}}-\mathrm{Si}$ and $\mathrm{Ca}-\mathrm{O}_{\mathrm{nb}}-\mathrm{Al}$, the relative constituents of which were figured out in Table 3. The conclusion can therefore be drawn that NBOs strongly prefer to be localized on $\mathrm{Si}$. This is probably because that the $\left[\mathrm{SiO}_{4}\right]$ tetrahedral unit does not need the charge balancing, resulting in more $\mathrm{Ca}$ playing the role of network modifier, cutting off $\mathrm{Si}-\mathrm{O}-\mathrm{T}$ linkages to form $\mathrm{Si}-\mathrm{O}_{\mathrm{nb}}-\mathrm{Ca}$, and the same consequence was acquired by the ${ }^{17} \mathrm{O}$ MAS NMR spectra ${ }^{1)}$ and high-energy $\mathrm{x}$ ray diffraction. ${ }^{27)}$ This also indicates that $\mathrm{Al}$ is more likely to coordinate with BOs.

Figure 4(b) shows the varying tendency of relative con- 
tents of three types of $\mathrm{BOs}$, that is $\mathrm{Si}-\mathrm{O}-\mathrm{Si}, \mathrm{Al}-\mathrm{O}-\mathrm{Al}$ and $\mathrm{Si}-\mathrm{O}-\mathrm{Al}$. The fractions of first two vary reasonably with increasing content of $\mathrm{Al}_{2} \mathrm{O}_{3}$, while $\mathrm{Si}-\mathrm{O}-\mathrm{Al}$ reaches the maximum of 0.50 for sample CAS6 when the number of $\mathrm{Si}$ atom is slightly larger than Al. To further reveal the relationship among three BO species, the interaction of them could be described by the reaction, ${ }^{1)}$

$$
\mathrm{Al}-\mathrm{O}-\mathrm{Al}+\mathrm{Si}-\mathrm{O}-\mathrm{Si} \leftrightarrow 2(\mathrm{Si}-\mathrm{O}-\mathrm{Al}) . .
$$

The calculated equilibrium constant $\mathrm{K}_{\mathrm{BO}}$ in the present simulation is $6.36 \pm 1.30$. The so-called 'Al avoidance' principle put forward that $\mathrm{Si}-\mathrm{O}-\mathrm{Al}$ linkage is energetically more favorable than $\mathrm{Al}-\mathrm{O}-\mathrm{Al}$ and $\mathrm{Si}-\mathrm{O}-\mathrm{Si}$ linkages. ${ }^{28)}$ To examine the accuracy of this principle, the degree of 'Al avoidance' was estimated in samples CAS1 and CAS11 by calculating the proportion of numbers of $\mathrm{Al}-\mathrm{O}-\mathrm{Al}$ linkages to the theoretic $\mathrm{Al}-\mathrm{O}-\mathrm{Al}$ numbers, and the estimated proportions are $61.7 \%$ and $94.9 \%$ for sample CAS1 and sample CAS11, respectively. This suggests that $\mathrm{Al}$ avoidance rule is more effective in $\mathrm{SiO}_{2}$-rich region. Similar results were observed by 3 Q MAS NMR spectra ${ }^{29)}$ and MD simulations. ${ }^{12)}$

The oxygen triclusters have been widely investigated about their existence, ${ }^{18,30)}$ conformation, ${ }^{31)}$ quantity ${ }^{12,13)}$ and influences on dynamics properties. ${ }^{11)}$ Number fractions of triclusters are traced and plotted in Fig. 4(a) with a prominent increase from $0.5 \%$ to $24 \%$ with increasing $\mathrm{Al}_{2} \mathrm{O}_{3} / \mathrm{SiO}_{2}$ ratio. A simple reaction $\mathrm{O}^{\mathrm{I}}+\mathrm{O}^{\mathrm{III}} \leftrightarrow 2 \mathrm{O}^{\mathrm{II}}\left(\mathrm{O}^{\mathrm{I}}, \mathrm{O}^{\mathrm{II}}\right.$ and $\mathrm{O}^{\mathrm{III}}$ represent NBOs BOs and triclusters respectively) describing the transition process of three $\mathrm{O}$ species was proposed and the equilibrium constant $\mathrm{K}_{\mathrm{O}}=\left[\mathrm{O}^{\mathrm{II}}\right]^{2} /\left[\mathrm{O}^{\mathrm{I}}\right]\left[\mathrm{O}^{\mathrm{III}}\right]$ (bracketed quantities refer to the number fractions of different $\mathrm{O}$ species) was equal to 49 in $2000 \mathrm{~K}$ calculated by Morgan and Spera. $^{20)}$ Thus the predicted concentration of $\mathrm{O}^{\mathrm{III}}$ was achieved by $\mathrm{K}_{\mathrm{O}}$ with $\left[\mathrm{O}^{\mathrm{II}}\right]$ as well as $\left[\mathrm{O}^{\mathrm{I}}\right]$ and displayed to compare with the simulated values. It can be seen that the calculated values are in agreement with simulated data. Oxygen triclusters are generally composed of $\mathrm{O}(\mathrm{Al}, \mathrm{Al}, \mathrm{Al})$, $\mathrm{O}(\mathrm{Al}, \mathrm{Al}, \mathrm{Si})$ and $\mathrm{O}(\mathrm{Al}, \mathrm{Si}, \mathrm{Si})$, and it is noted that the proportion of $\mathrm{O}(\mathrm{Al}, \mathrm{Si}, \mathrm{Si})$ is less than $0.5 \%$ and no $\mathrm{O}(\mathrm{Si}, \mathrm{Si}$, $\mathrm{Si}$ ) was observed (Fig. 4(b)). This is probably because that triclusters play the role of charge compensating to $\left[\mathrm{AlO}_{4}\right]$ tetrahedron, whereas $\left[\mathrm{SiO}_{4}\right]$ tetrahedron is electrically neutral so that it is very difficult for the stable $\mathrm{Si}-\mathrm{O}_{\mathrm{b}}-\mathrm{Si}$ site to be coordinated with a third cation to form $\mathrm{O}(\mathrm{Al}, \mathrm{Si}, \mathrm{Si}$ ) or $\mathrm{O}(\mathrm{Si}, \mathrm{Si}, \mathrm{Si})$. As shown in Fig. 5, triclusters can also be treated as the corner shared by three tetrahedrons, two of which, mostly both $\left[\mathrm{AlO}_{4}\right]$ tetrahedrons, have a certain probability to share an edge $(\mathrm{O}-\mathrm{O})$. But this edge-sharing phenomenon seems not applicable between $\left[\mathrm{SiO}_{4}\right]$ and $\left[\mathrm{AlO}_{4}\right]$, whose edges are unstable with each other and will undoubtedly give rise to structural distortion and a rapid energetic raise if edge-sharing occurs.

In summary, the concentration of $\mathrm{NBO}$ decreases from $28.5 \%$ to $5.9 \%$ with increasing $\mathrm{Al}_{2} \mathrm{O}_{3} / \mathrm{SiO}_{2}$ ratio and $\mathrm{NBO}$ prefers to be localized on $\mathrm{Si}$. The degree of $\mathrm{Al}$ avoidance is applicable in $\mathrm{SiO}_{2}$ rich region. An increasing $\mathrm{Al}_{2} \mathrm{O}_{3} / \mathrm{SiO}_{2}$ ratio gives rise to oxygen triclusters which are mainly composed of $\mathrm{O}(\mathrm{Al}, \mathrm{Al}, \mathrm{Al})$ and $\mathrm{O}(\mathrm{Al}, \mathrm{Al}, \mathrm{Si})$.

\subsection{Distributions of 5-coordinated $A l$ and $Q^{\mathbf{n}}$}

Figure 6(a) illustrates the distribution of $\mathrm{Al}$ with different

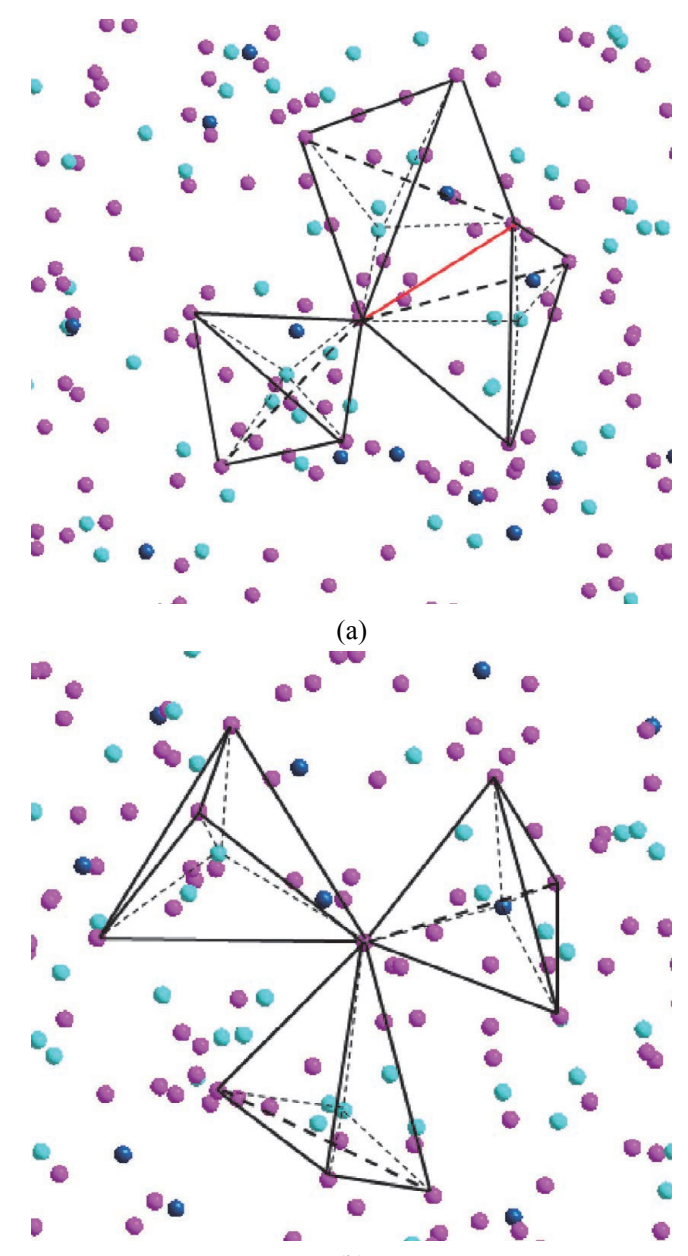

(b)

Fig. 5. Configurations of different types of oxygen triclusters. (a) The $\mathrm{O}$ atom shared by three $\mathrm{AlO}_{4}$ tetrahedrons, two of which have a common edge; (b) the $\mathrm{O}$ atom shared by two $\mathrm{AlO}_{4}$ tetrahedrons and one $\mathrm{SiO}_{4}(\mathrm{Si}, \mathrm{Al}, \mathrm{O}$ atoms are marked by balls with the color of deep blue, light blue and pink, respectively. $\mathrm{Si}(\mathrm{Al})$ tetrahedrons are outlined by thick lines and thin dash lines represent $\mathrm{Si}-\mathrm{O}$ or $\mathrm{Al}-\mathrm{O}$ bonds. Red line in (a) is the edge shared by two tetrahedrons).

coordination number as a function of $\mathrm{Al}_{2} \mathrm{O}_{3}$ mole fraction. It should be noted that the concentration of $\mathrm{Al}^{\mathrm{IV}}$ preponderates over others with a percentage more than $87 \%$. The concentration of $\mathrm{Al}^{\mathrm{V}}$ varies from $4 \%$ to $10 \%$ in an indistinct way with composition, and reaches the maximum as the $\mathrm{SiO}_{2}$ content is $40 \mathrm{~mol} \%$ corresponding to sample CAS7. $\mathrm{Al}^{\mathrm{V}}$ increases dramatically from $5.5 \%$ to $9.4 \%$ in CAS6 and CAS7, and decreases slightly to $7.8 \%$ in CAS8. This irregular variation can be interpreted by the amphoteric character of Al. That is, the substitution of $\mathrm{Al}$ for $\mathrm{Si}$ gives rise to a change of the role of $\mathrm{Al}$ from an acid to an alkali. The separation line of the variation is CAS7, where the molar ratio $\mathrm{Al}_{2} \mathrm{O}_{3} / \mathrm{CaO}$ equals to 1 . The ${ }^{27} \mathrm{Al}$ MAS NMR spectra ${ }^{15)}$ reported the similar fraction of $\mathrm{Al}^{\mathrm{V}}$ (4\% to $8.9 \%$ ) in $\mathrm{SiO}_{2}$ rich glasses. Another NMR experiment ${ }^{16)}$ and a molecular modeling study ${ }^{11)}$ reported that the concentration of $\mathrm{Al}^{\mathrm{V}}$ exhibits a maximum value $(7.2 \%)$ as the silica content is around $35 \mathrm{~mol} \%$ at a fixed $\mathrm{CaO} / \mathrm{Al}_{2} \mathrm{O}_{3}$ ratio equal to 1 . The $\mathrm{Al}^{\mathrm{III}}$ should also be taken notice of especially in the first five CAS slags with the fraction of $4 \%$, where enough Ca cations are present to provide charge compensation of $\left[\mathrm{AlO}_{4}\right]$ tetrahedron. Meanwhile, $\mathrm{Al}^{\mathrm{VI}}$ is barely observed in our samples 


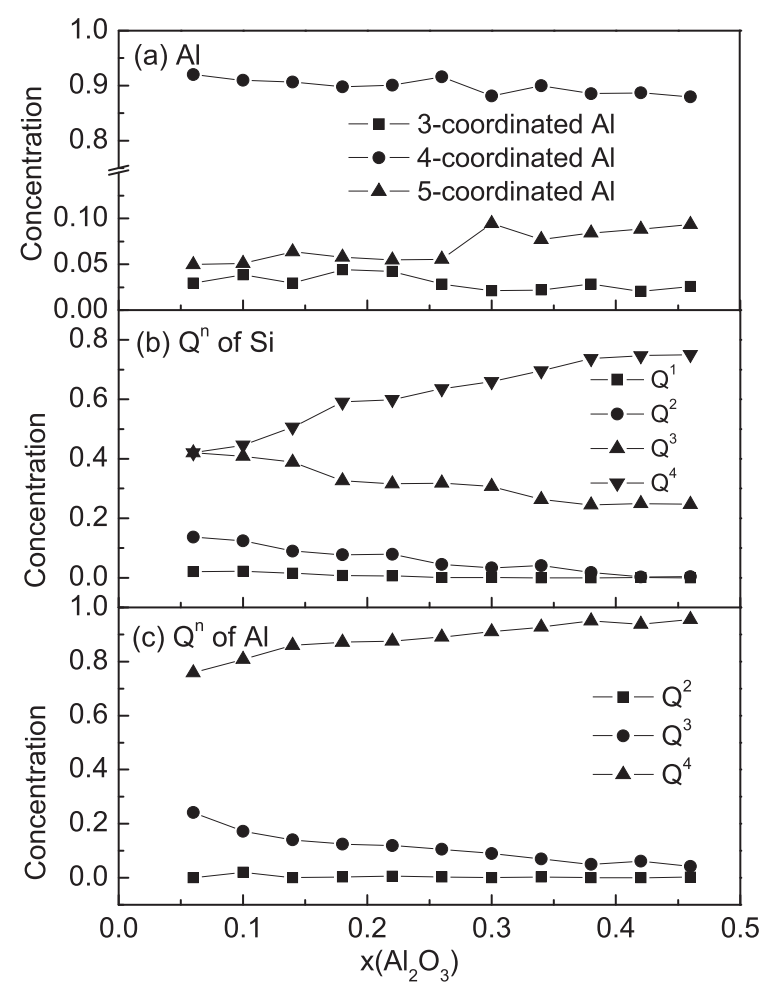

Fig. 6. (a) Concentration of $\mathrm{Al}$ coordinated with different numbers of $\mathrm{O}$, (b) distributions of $\mathrm{Q}^{\mathrm{n}}$ of $\mathrm{Si}$ versus mole fraction of $\mathrm{Al}_{2} \mathrm{O}_{3}$; (c) distributions of $\mathrm{Q}^{\mathrm{n}}$ of $\mathrm{Al}$ versus mole fraction of $\mathrm{Al}_{2} \mathrm{O}_{3}$.

(less than $0.3 \%$ ) and is therefore not considered to be significant. Furthermore, taking the three types of oxygen into account, the formation of $\mathrm{Al}^{\mathrm{V}}$ can be interpreted by three reactions, ${ }^{11)}$

$$
\begin{gathered}
\mathrm{Al}^{\mathrm{IV}} \leftrightarrow \mathrm{Al}^{\mathrm{III}}+\mathrm{O}^{\mathrm{I}} \ldots \ldots . . . \\
\mathrm{Al}^{\mathrm{III}}+\mathrm{O}^{\mathrm{II}} \leftrightarrow \mathrm{Al}^{\mathrm{IV}}+\mathrm{O}^{\mathrm{III}} \\
\mathrm{Al}^{\mathrm{IV}}+\mathrm{O}^{\mathrm{I}} \leftrightarrow \mathrm{Al}^{\mathrm{V}} \ldots \ldots . . .
\end{gathered}
$$

As the intermediate phase of reactions, $\mathrm{Al}^{\mathrm{V}}$ and triclusters intensively affect the structural properties of CAS slags, such as self-diffusion coefficients.

Figures 6(b) and 6(c) elucidate the proportion of $Q^{n}(n$ is the number of $\mathrm{BO}$ and oxygen tricluster in one tetrahedron) in $\left[\mathrm{SiO}_{4}\right]$ and $\left[\mathrm{AlO}_{4}\right]$ tetrahedral units shifting with $\mathrm{Al}_{2} \mathrm{O}_{3} / \mathrm{SiO}_{2}$ ratio. It can be seen that the concentration of $\mathrm{Q}^{4}$ increases dramatically at the cost of a decreasing in $\mathrm{Q}^{2}$ and $\mathrm{Q}^{3}$ and shares a similar variation trend with the total fraction of $\mathrm{O}^{\mathrm{II}}$ and $\mathrm{O}^{\mathrm{III}}$. The degree of polymerization (DOP) can be measured by $\left(Q^{4}+Q^{3}\right) /\left(Q^{2}+Q^{1}\right)$ and therefore increases with $\mathrm{Al}_{2} \mathrm{O}_{3} / \mathrm{SiO}_{2}$ ratio. This further indicates that the viscosity of CAS slags may increase as $\mathrm{SiO}_{2}$ is replaced by $\mathrm{Al}_{2} \mathrm{O}_{3}$, for a given $\mathrm{CaO}$ content. Most available viscosity data ${ }^{32,33)}$ agree well with our conclusion. In the ternary slag systems of $\mathrm{K}_{2} \mathrm{O}-\mathrm{Al}_{2} \mathrm{O}_{3}-\mathrm{SiO}_{2}$ at $1350^{\circ} \mathrm{C}, \mathrm{Na}_{2} \mathrm{O}-\mathrm{Al}_{2} \mathrm{O}_{3}-\mathrm{SiO}_{2}$ at $1500^{\circ} \mathrm{C}$ and $\mathrm{CaO}-\mathrm{Al}_{2} \mathrm{O}_{3}-\mathrm{SiO}_{2}$ at $1550^{\circ} \mathrm{C}$ when the mole fraction of $\mathrm{CaO}$ exceeds 0.4 , the viscosity increases monotonically with the increase of $\mathrm{Al}_{2} \mathrm{O}_{3} / \mathrm{SiO}_{2}$ molar ratio. But for $\mathrm{CaO}-\mathrm{Al}_{2} \mathrm{O}_{3}-$ $\mathrm{SiO}_{2}$ slags at $1550^{\circ} \mathrm{C}$, the viscosity reveals a decreasing trend with an increasing $\mathrm{Al}_{2} \mathrm{O}_{3} / \mathrm{SiO}_{2}$ ratio when the mole fraction of $\mathrm{CaO}$ equals to 0.3 and $\mathrm{Al}_{2} \mathrm{O}_{3}$ less than $0.25 .^{32)}$ In fact, the viscosity of the slags is determined not only by
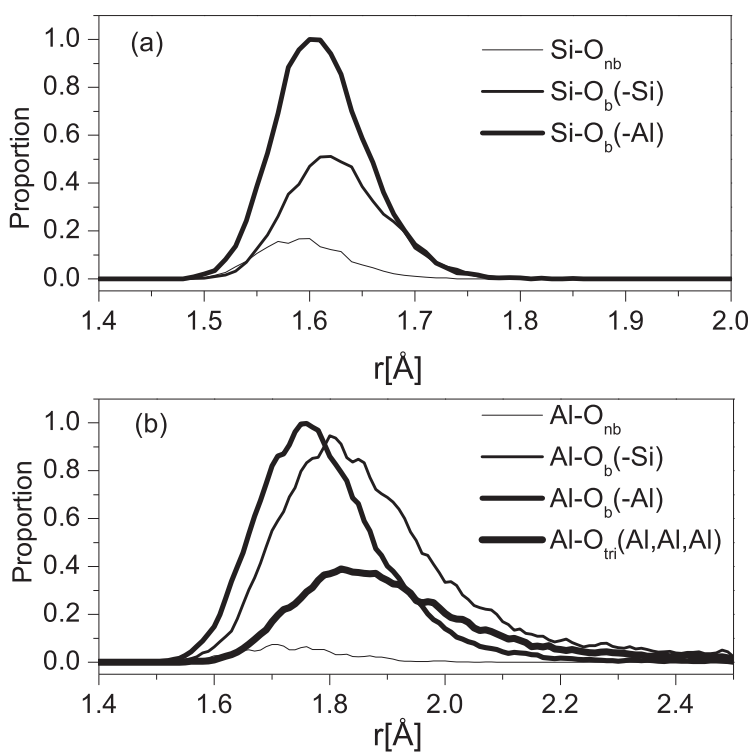

Fig. 7. (a) Distributions of $\mathrm{Si}-\mathrm{O}$ and (b) $\mathrm{Al}-\mathrm{O}$ bond lengths.

DOP but also by the strength of polymerization, which is reduced by the substitution of $\left[\mathrm{AlO}_{4}\right]$ for $\left[\mathrm{SiO}_{4}\right]$ due to the instability of $\mathrm{Al}-\mathrm{O}$ bonds compared with $\mathrm{Si}-\mathrm{O}$. The exceptions are therefore reasonable to some extent if we take both factors into consideration. In the present 11 studied samples, $\mathrm{Q}^{4}$ always advantages over other $\mathrm{Q}^{\mathrm{n}}$ species, while $\mathrm{Q}^{0}$ and $\mathrm{Q}^{1}$ can be neglected due to their tiny quantity. The contents of $\mathrm{Q}^{2}$ and $\mathrm{Q}^{3}$ exhibit a maximum value in sample CAS1 where most NBOs are observed because $\mathrm{Ca}$ is far beyond that required for charge compensation. Comparing Fig. 6(b) with 6(c) it should be noted that the concentration of $\mathrm{Q}^{4}$ in $\mathrm{Al}$ invariably exceeds that in $\mathrm{Si}$, suggesting that $\mathrm{Al}$ is preferentially localized in the more polymerized environments acting as the network intermediates, while $\mathrm{Si}$ is more likely to act as terminals at the network boundaries. Same results were also reported by high-energy x-ray diffraction in CAS glasses ${ }^{27)}$ and ${ }^{29} \mathrm{Si} \mathrm{NMR}$ in $\mathrm{Na}$ containing aluminosilicate glasses. ${ }^{34)}$

It can be concluded that the concentration of $\mathrm{Al}^{\mathrm{V}}$ varies from $4 \%$ to $10 \%$ and its character changes from acid to alkali as the molar ratio of $\mathrm{Al}_{2} \mathrm{O}_{3} / \mathrm{SiO}_{2}$ equal to the unit. The concentration of $\mathrm{Q}^{4}$ increases dramatically at the cost of a decreasing in $\mathrm{Q}^{2}$ and $\mathrm{Q}^{3}$ with increasing $\mathrm{Al}_{2} \mathrm{O}_{3} / \mathrm{SiO}_{2}$ ratio, indicating a high DOP of the system. $\mathrm{Al}$ is preferentially localized in the more polymerized environments acting as the network intermediates.

\subsection{Distributions of Bond Lengths and Bond Angles}

RDF offers some fundamental information about distribution of bond lengths without classification. In fact, bond lengths of $\mathrm{Si}-\mathrm{O}$ and $\mathrm{Al}-\mathrm{O}$ differ according to the diversity of the oxygen environments, as illustrated in Fig. 7, and three types of $\mathrm{Si}-\mathrm{O}$ distances $\left(\mathrm{Si}-\mathrm{O}_{\mathrm{nb}}, \mathrm{Si}-\mathrm{O}_{\mathrm{b}}-\mathrm{Si}, \mathrm{Si}-\mathrm{O}_{\mathrm{b}}-\mathrm{Al}\right)$ and four kinds of $\mathrm{Al}-\mathrm{O}$ distances $\left(\mathrm{Al}-\mathrm{O}_{\mathrm{nb}}, \mathrm{Al}-\mathrm{O}_{\mathrm{b}}-\mathrm{Si}, \mathrm{Al}-\right.$ $\mathrm{O}_{\mathrm{b}}-\mathrm{Al}, \mathrm{Al}-\mathrm{O}_{\text {tri }}$ ) for sample CAS7 are included. All curves are normally distributed and the height of them represents the concentration of different types of oxygen. The sequences of the lengths are $\mathrm{Si}-\mathrm{O}_{\mathrm{nb}}(-\mathrm{Ca})<\mathrm{Si}-\mathrm{O}_{\mathrm{b}}(-\mathrm{Al})<\mathrm{Si}-\mathrm{O}_{\mathrm{b}}(-$ $\mathrm{Si})$ and $\mathrm{Al}-\mathrm{O}_{\mathrm{nb}}(-\mathrm{Ca})<\mathrm{Al}-\mathrm{O}_{\mathrm{b}}(-\mathrm{Al})<\mathrm{Al}-\mathrm{O}_{\mathrm{b}}(-\mathrm{Si})<\mathrm{Al}-\mathrm{O}_{\text {tri }}$, and this agrees well with the attractive force between $\mathrm{O}$ and 


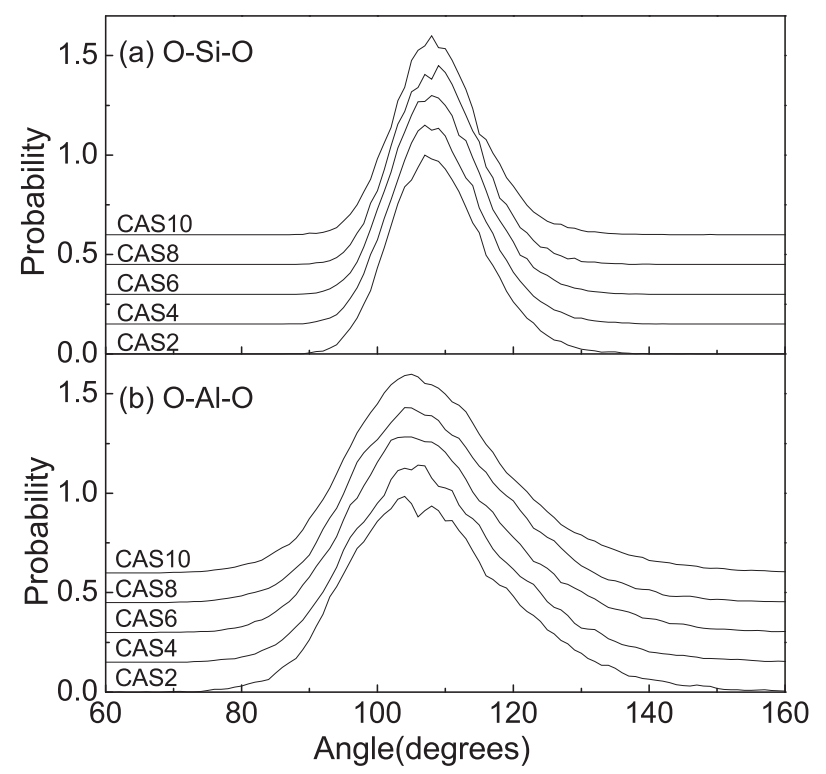

Fig. 8. (a) Distributions of $\mathrm{O}-\mathrm{Si}-\mathrm{O}$ and (b) $\mathrm{O}-\mathrm{Al}-\mathrm{O}$ angles in tetrahedral units with varying $\mathrm{Al}_{2} \mathrm{O}_{3} / \mathrm{SiO}_{2}$ ratio.

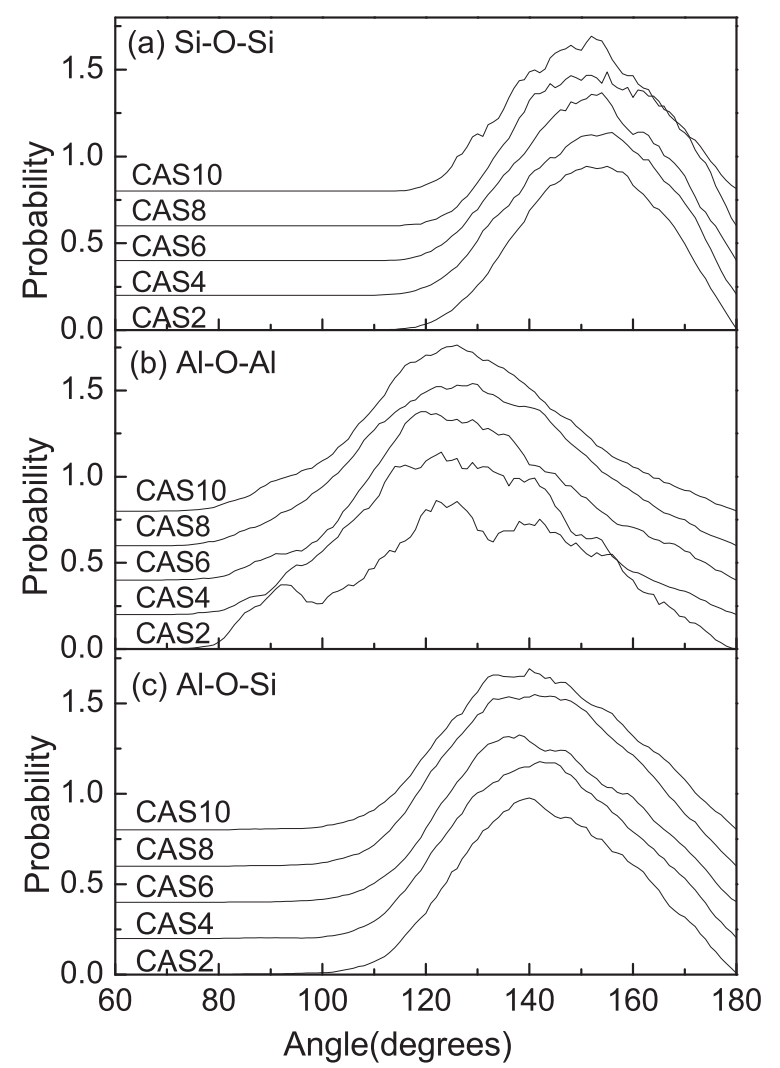

Fig. 9. (a) Distributions of $\mathrm{Si}-\mathrm{O}-\mathrm{Si}$, (b) $\mathrm{Al}-\mathrm{O}-\mathrm{Al}$ and (c) $\mathrm{Al}-\mathrm{O}-\mathrm{Si}$ with varying $\mathrm{Al}_{2} \mathrm{O}_{3} / \mathrm{SiO}_{2}$ ratio.

cations $(\mathrm{Ca}<\mathrm{Al}<\mathrm{Si})$. The third $\mathrm{Al}$ being coordinated to $\mathrm{Al}-\mathrm{O}-\mathrm{Al}$ influences the charge arrangement of oxygen and elongates $\mathrm{Al}-\mathrm{O}$ bonds to $1.92 \AA$ in average and the less stable structure of $\left[\mathrm{AlO}_{4}\right]$ tetrahedron gives rise to a wider distribution of $\mathrm{Al}-\mathrm{O}$ than that of $\mathrm{Si}-\mathrm{O}$.

The distributions of OSiO, OAlO, SiOSi, AlOAl and AlOSi angles of 5 samples are presented in Figs. 8 and $\mathbf{9 ,}$ respectively. The $\mathrm{OSiO}$ and $\mathrm{OAIO}$ angular distributions present a quite symmetric shape in all CAS compositions averaging at $109.3^{\circ}$ and $108.8^{\circ}$ respectively, which are very close to the ideal tetrahedral angle $\left(109.5^{\circ}\right)$. Just as the bond lengths show, a wider distribution of angles is also observed in OAlO than in OSiO. The angular distributions of SiOSi, AlOAl and AlOSi are somewhat noisy because of the defects in process of statistics and exhibit an asymmetric shape with the average values around $152^{\circ}, 129^{\circ}$ and $140^{\circ}$, respectively. The average AlOSi angle is smaller than $\mathrm{SiOSi}$ but larger than AlOAl, which is consistent with the tendency that the $\mathrm{T}-\mathrm{O}-\mathrm{T}$ angles increase as the average length of two bonds in $\mathrm{T}-\mathrm{O}-\mathrm{T}$ decreases. ${ }^{12)}$ It should be pointed out that the angular distributions of SiOSi for sample CAS10 and AlOAl for sample CAS2 do not present a clear maximum value as others due to the low numbers of the linkages. In the three types of angles, the average angle of AlOSi decreases obviously from $142^{\circ}$ to $136^{\circ}$ with an increasing $\mathrm{Al}_{2} \mathrm{O}_{3} / \mathrm{SiO}_{2}$ ratio, which is attributed to the increasing interactions between modifiers' network and polymerized network, ${ }^{35)}$ resulting in more triclusters coordinated with Al.

In conclusion, the oxygen environments strongly affect the bond length of $\mathrm{Si}-\mathrm{O}$ and $\mathrm{Al}-\mathrm{O}$, and further affect the distributions of bond angles, which also vary regularly with increasing $\mathrm{Al}_{2} \mathrm{O}_{3} / \mathrm{SiO}_{2}$ ratio.

\section{Conclusions}

Molecular dynamics simulation was carried out on a series of ternary slags $\mathrm{CaO}-\mathrm{SiO}_{2}-\mathrm{Al}_{2} \mathrm{O}_{3}$ with different composition to study the structural properties of these systems, and the results are as follows,

(1) The substitution of $\mathrm{Al}_{2} \mathrm{O}_{3}$ for $\mathrm{SiO}_{2}$ enhances the degree of polymerization of the slags at a fixed $\mathrm{CaO}$ concentration, which can be indicated from the decreasing NBOs and increasing $\mathrm{Q}^{4}$ complexes. The viscosity of the sample may increase with increasing $\mathrm{Al}_{2} \mathrm{O}_{3} / \mathrm{SiO}_{2}$ molar ratio but it is also influenced by the strength of polymerization.

(2) There is an obvious preference for NBO to be coordinated with $\mathrm{Si}$ while Al tends to be localized in more polymerized environment as network intermediate phases.

(3) Al avoidance principle is partially applicable especially in the silica rich regions.

(4) Oxygen triclusters are mostly composed of O(Al, $\mathrm{Al}, \mathrm{Al})$ and $\mathrm{O}(\mathrm{Al}, \mathrm{Al}, \mathrm{Si})$ and increase with the increasing $\mathrm{Al}_{2} \mathrm{O}_{3} / \mathrm{SiO}_{2}$ ratio. The formation process is to some extent connected with that of $\mathrm{Al}^{\mathrm{V}}$.

(5) The distribution of bond angles interrelates with that of bond lengths and they are both influenced by the composition of slags.

\section{Acknowledgements}

The authors wish to express their gratitude to Prof. Yongquan $\mathrm{Wu}$ for his help and suggestions during the simulation process. Financial supports from National Natural Science Foundation of China (50902003,51172003) and National Key Technology Research and Development Program (2010BAE00316) are gratefully acknowledged.

\section{REFERENCES}

1) J. R. Allwardt, S. K. Lee and J. F. Stebbins: Am. Mineral., 88 (2003), 949.

2) K. Kanshashi and J. F. Stebbins: J. Non-Cryst. Solids, 353 (2007), 4001.

3) S. K. Lee and J. F. Stebbins: Geochim. Cosmochim. Acta, 70 (2006), 
4275 .

4) S. K. Lee and J. F. Stebbins: J. Non-Cryst. Solids, 270 (2000), 260.

5) Z. Wu, C. Romano, A. Marcelli, A. Mottana, G. Cibin, G. Della Ventura, G. Giuli, P. Courtial and D. B. Dingwell: Phys. Rev. B, 60 (1999), 09833-1.

6) D. R. Neuville, L. Cormier, A.-M. Flank, V. Briois and D. Massiot: Chem. Geol., 213 (2004), 153.

7) L. Cormier, D. R. Neuville and G. Calas: J. Non-Cryst. Solids, 274 (2000), 110.

8) A. C. Hannon and J. M. Parker: J. Non-Cryst. Solids, 274 (2000), 102.

9) G. C. Jiang, J. L. You, Y. Q. Wu, H. Y. Hou and H. Chen: Geol. Geochemistry, 31 (2003), No. 4, 0080-07.

10) L. G. Hwa, S. L. Hwang and L. C. Liu: J. Non-Cryst. Solids, 238 (1998), 193.

11) A. Tandia, N. T. Timofeev, J. C. Mauro and K. D. Vargheese: J. NonCryst. Solids, 357 (2011), 1780

12) L. Cormier, D. Ghaleb, D. R. Neuville, J.-M. Delaye and G. Calas: J. Non-Cryst. Solids, 332 (2003), 255.

13) P. Ganster, M. Benoit, W. Kob and J.-M. Delaye: J. Chem. Phys., 120 (2004), 10172.

14) L. Y. Xu, X. L. Wang, Y. Q. Wu and G. C. Jiang: J. Chin. Ceram. Soc., 34 (2006), No. 9, 1117-07.

15) J. F. Stebbins, E. V. Dubinsky, K. Kanehashi and K. E. Kelsey: Geochim. Cosmochim. Acta, 72 (2008), 910.

16) D. R. Neuville, L. Cormier and D. Massiot: Chem. Geol., 229 (2006), 173.

17) M. Benoit, S. Ispas and M. Tuckerman: Phys. Rev. B, 64 (2001), 224205-1.

18) J. F. Stebbins, J. V. Oglesby and S. Kroeker: Am. Mineral., 86 (2001),
1307.

19) Y. Q. Wu, G. C. Jiang, J. L. You, H. Y. Hou and H. Chen: J. Central South Univ. Technol., 11 (2004), 6.

20) N. A. Morgan and F. J. Spera: Am. Mineral., 86 (2001), 915

21) D. R. Neuville, L. Cormier, V. Montouillout and D. Massiot: J. NonCryst. Solids, 353 (2007), 180.

22) W. L. Wang, K. Blazek and A. Cramb: Metall. Mater. Trans. B, 39 (2008), 66.

23) P. Courtial and D. B. Dingwell: Am. Mineral., 84 (1999), 465.

24) P. Ganster, M. Benoit, J.-M. Delaye and W. Kob: Surf. Sci., 602 (2008), 114.

25) D. R. Neuville, L. Cormier, D. de Ligny, J. Roux, A.-M. Flank and P. Lagarde: Am. Mineral., 93 (2008), 228.

26) J. F. Stebbins and Z. Xu: Nature, 390 (1997), 60

27) V. Petkov, S. J. L. Billinge, S. D. Shastri and B. Himmel: Phys. Rev. Lett., 85 (2000), 3436.

28) W. Loewenstein: Am. Mineral., 39 (1954), 92.

29) S. K. Lee and J. F. Stebbins: Am. Mineral., 84 (1999), 937.

30) M. Schmucker and H. Schneider: J. Non-Cryst. Solids, 311 (2002), 211.

31) X. Xue and M. Kanzaki: J. Phys. Chem. B, 103 (1999), 10816.

32) K. C. Mills: Slag Atlas, Verein Deutscher Eisenhüttenleute (VDEh), 2nd ed., Germany, (1995), 364.

33) Z. T. Zhang, G. H. Wen, P. Tang and S. Sridhar: ISIJ Int., 48 (2008), 739.

34) H. Maekawa, T. Maekawa, K. Kawamura and T. Yokokawa: J. NonCryst. Solids, 127 (1991), 53.

35) F. Angeli, J.-M. Delaye, T. Charpentiel, J.-C. Petit, D. Ghaleb and P. Faucon: Chem. Phys. Let., 320 (2000), 681. 